\title{
Electroanalytical Chemistry: Research Developments, Jiang, P.N., Ed., New York: Nova Science Publishers, 2007, 313 p.
}

DOI: $10.1134 / \mathrm{S} 1023193509050231$

Elder researchers may remember Frank Columbus, in 1980s the head of the Translation Department of Consultants Bureau, a Division of Plenum Publishing Corporation (USA). Under his supervision, a number of monographs of Soviet authors was translated and published in USA. Later, F. Columbus left Plenum and founded his own publishing house, Nova Science Publishers, which publishes books in different fields of science and engineering, in particular, in electrochemistry. For example, in the latest years they issued Electroanalytical Chemistry Research Trends (2008), Electroanalytical Chemistry: New Research (2008), Bioelectrochemistry Research Developments (2008), Electrochemistry: New Research (2008), Electrochemical Studies of Batteries (2007), Trends in Electrochemistry Research (2007), New Topics in Electrochemistry Research (2006), Focus on Electrochemistry Research (2005), Metal Electrodeposition (2005), and Progress in Electrochemistry Research (2005)-they all are the collected articles. Such is the reviewed book. Now we consider very briefly its contents.

The book begins with brief communication "Novel perspectives of the application of scanning electrochemical microscopy (in the book an error: spectroscopy) in the study of electrocatalytic reactions" by Lin Niu, Xiaoli Cao, and Min Lu. In Chapter 1, T. Okada, M. Saito, and K. Hayamizu consider ion and water transport in Nafion-type membranes for fuel cells. Special attention is paid to the preventing of the cell operational characteristics degradation caused by the membrane contamination by foreign cations, as well as to the elucidating of the mechanism of ionic and water transport in the membrane. Chapter 2 is devoted to polymer electrolytes for fuel cells. Operational charac- teristics of the cells assembled by authors (J. Qiao and T. Okada) are presented. In Chapter 3, L.E. Tsygankova, V.I. Vigdorovich, and M.V. Vigdorovich discuss the kinetics of hydrogen evolution at iron membranes from $\mathrm{HCl}$ solutions in ethylene glycol and methanol and its diffusion through the membranes. Two forms of adsorbed hydrogen (the surface and subsurface ones) are taken into consideration. And yet, the authors' approach appears being somewhat out of date (who refers to the N. Kobozev's theory nowadays, indeed!). In Chapter 4, the fundamentals of the synthetic diamond electrochemistry and the using of diamond electrodes in the electrosynthesis and electroanalysis are formulated by the author of the present Review. Chapter 5 by E. Mirmomtaz and A.A. Ensafi is devoted to the determination of trace and ultra-trace concentrations of toxic agents and pollutants, especially, to the improving of selectivity and sensitivity of electrochemical and optical methods of analysis. A similar problem, i.e., determination of trace amounts of metals (by the example of methylglyoxime complexes of $\mathrm{Ni}, \mathrm{Co}$, and $\mathrm{Pd}$ ) is approached in Chapter 6 (S.A. Ramirez, G.J. Gordillo) by using the adsorptive stripping voltammetry. The final Chapter 7 (B. Bozzini, L. D'Urzo, and C. Mele) is devoted to the applying of electrodeposited $\mathrm{Au}-\mathrm{Pd}$ alloys as catalysts for anodes in the direct methanol oxidation fuel cell. Here special emphasis is made on the alloy structures.

On the whole, the book gives a clear insight into the state-of-art of the listed fields in electrochemistry. It is supplied by Index. The graphic arts quality is good, except some figures that are rather coarse.

Yu. V. Pleskov 